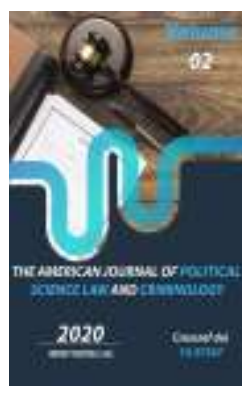

\title{
The Perfection Of Organizational Bases Of Functioning Of The Institute Of Self-Government Bodies
}

\author{
Gulnoza Ismailova \\ DSc In Law, Associate Professor, Vice-Rector For Science And Innovation, University Of World \\ Economy And Diplomacy, Tashkent, Uzbekistan
}

Journal Website: http://usajournalshub.c om/index,php/tajpslc

Copyright: Original content from this work may be used under the terms of the creative commons attributes 4.o licence.

\section{ABSTRACT}

This article is devoted to the issues of the role of Mahalla in the development of society, strengthening the place and role of self-government bodies of citizens in political processes, turning them into a local structure that provides real support and assistance to the people, expanding the direct participation of self-governing institution in ensuring public order and security.

Moreover, the author analyzed the features and results of new reforms in Uzbekistan carried out in the economic, social, political spheres to increase the role of self-government bodies. In addition, the scientific work presents some proposals for enhancing the socio-political activity of Mahalla, strengthening their role in managing the state and society.

\section{KEYWORDS}

Civil society, community, local government, mahalla, self-government, self-governing institution, socio-economic integration, traditional values, cooperation.

\section{INTRODUCTION}

Today, one of the key issues in improving local government is the development of a scientifically based concept of the institution of self-government, the essence of which is its role in the development of the state and society.

During the years of independence of the Republic of Uzbekistan, the phrase "self- government bodies" has been enriched with a clear meaning and penetrated into the wider society. However, the importance of the relationship between the role and place of the institution of self-government in state building is not always understood and accepted.

The experience of state building and administration in the East has certain 
peculiarities. Today, as in ancient times, a Mahalla is a community of people connected not only by neighboring relations, but also by centuries-old traditions and customs. The form of socio-economic integration of the population has changed in the course of historical development.

From ancient times, the system of selfgovernment in the territory of our country has been implemented in the form of "Mahalla". Mahalla is the most ancient and unique structure which incorporates the traditional values of the Uzbek people, providing spiritual and social support to its residents. The experience of state building and its management has always had its own peculiarities on the continent of Asia and in the Muslim east. Long before the Arab conquest and the adoption if the Islamic religion, Mahalla existed as a Union of People living in certain area where they were connected not only by neighborly ties, but also by spiritual and ethical norms, customs and ancient traditions, and internal regulations established for centuries [1, P. 142-143]. Although the name Mahalla was granted to self-governing territories after the conquest of the Arabs, this concept stands for a community of citizens. Everyone had the opportunity to take the initiative in solving various public interest related issues. People actively used their right to tackle the gardening of their territory, assistance to the poor and education of the younger generation. Through the Mahalla, reforms in different aspects of the socio-economic, political and cultural life effected many Uzbek families [2, P.142].

Within the structure of Uzbek civil society everything has its place and role - the individual, the family, the Mahalla, different non-governmental and non-profit organizations, and other social institutions including political parties, movements, communities and etc. Mahalla has a specific role as a self-governing institution within this structure. Mahalla reflects how diverse and unique the regions of the country are and it works as a mechanism that is similar to instruments used by other institutions of civil society. Of course, in the conditions of an independent and secular state Mahalla has an enriched meaning. Preserving the appropriate elements of communalism, Mahalla is being transformed into a secular, modern mechanism of self-governance [3, P.13].

\section{The Dilemma Of Concept}

The social experience of mankind shows that the form of self-organization in solving everyday problems has not been observed at all stages of state development. If we reflect on the principles and forms of the organization of citizens' self-government, we are convinced that they were formed in the process of longlasting dialectical confrontations of society and the state and came into being as a result of political struggles. Modern principles and forms of self-government are a complex process of seeking a framework of mutual compromise between the territorial community and the state and the result of reconciliation in the public interest.

Until recently, a key concept in the definition of self-government was "independence". Effective implementation of the principle of autonomy implies the existence of a system of self-government special powers, allowing them either to decide the issues in the public interest, or participate in the formulation and decision making at the level of government, if

\footnotetext{
${ }^{1}$ Mahalla - is a citizens' self-governing institution.
} 
these decisions affect the interests of selfgovernment.

The evolution of views on the role of local government could not lead to a reassessment of the principles that should govern the interaction of state authority and selfgovernance. Separate self-governing bodies of the organs of the state are more political in nature and very difficult to be translated into concrete legal formulas. As the political and legal category, constitute a form of organization that implements the laws inherent in any social management process in general and public administration in particular.

The government can influence local government only by means of the general regulation, and it is quite enough of it for maintenance of unity of the government. Local government is not a subsystem of any structural element of the government. Local government - is a special socio-political phenomenon, a type of public authority. Local government is a structure with a specific impetus for the development of statehood.

The principle of detailed delineation of authority and sources of funding between levels of government, consistently implemented by the state currently requires the introduction of mechanisms that would allow the levels of public administration at a lower level feel, first of all, protected from arbitrary shifting them non-core tasks and functions, and secondly, in the case of transfer of powers from one level to another should be guaranteed the transfer and necessary for the implementation of material and financial resources.

An important component of the formation of the doctrine of self-government is a clarification of the legal nature of government, its dualistic (dual) character. Solution to this problem was complicated by a number of circumstances.

First of all, this was due to the fact that the self as a phenomenon in many ways a natural state of man and society, which distinguishes it from the state. Tradition of self-originated long before the creation of the first public entities. Clarification of the legal nature of selfgovernment was due to the simultaneous consideration of several interrelated issues: the ratio of local government traditions and self-governance, understanding of general and special in the fact of state power and selfgovernance, the relationship of local control and self-governance, etc.

\section{Increasing the role of Mahalla}

Mahalla has always been the center of public opinion, the preservation of national values, and the solution of pressing life problems. President Shavkat Mirziyoyev rightly noted that the Mahalla should be the abode of peace and tranquility, mutual respect and education [4]. A necessary condition for sustainable development of the country is the existence of a self-government system, which is very important for Uzbekistan than for most foreign models of government.

The current concept of citizen self-government represents one of the liberal forms of government that can be organized at the local level of the population, i.e. in a particular area of residence. The process of emergence and development of the institution of modern civic self-government is also, as noted, an objective and inevitable process. Because the current principle of the organization of citizens' selfgovernment is a specific form of the integral 
fundamental property of all social systems, that is, the property of self-organization.

Objective scientific analysis of selfgovernment, its legal nature in the 1990s and strengthened the sequence of reforms, elected constitutional-legal model of selfgovernment. An effective legal policy related to the correlation of the model chosen selfgovernment with the form and traditions of our state system of public authorities and the general principles of her organization, sociocultural characteristics, the mentality of the population, the unfolding global processes, and other objective and subjective conditions and factors in the development of state and society.

The nature of the Uzbek model of self-being as a whole institution of public power, it draws in its nature a number of social traits. The presence of these features, the presence of a particular level of management, the existence of a special sphere of social relations associated with the solution of local issues, just also allows you to separate self-governing citizens of the state, highlight it in a separate entity with its unique nature: in many states, but with elements of the public.

The first President of the Republic of Uzbekistan Islam Karimov at joint session of Legislative chamber and Senate of the Oliy Majlis of the Republic of Uzbekistan on the 12 of November 2010, stated “... Special urgency the further perfection of organizational bases of functioning of institute of self-government of citizens - Mahalla gets expansion of functions and maintenance of its close interaction with state governing bodies". Today, reforms in this area are also actively continuing under the leadership of the President of Uzbekistan Shavkat Mirziyoyev.
Self-government of citizens and the government are closely interrelated; it is because they have a common source - the power of the people. The public power which is carried out by self-government of citizens is especial, different both from state, and from public. The decision of self-government bodies shall be binding in its territory. In many cases, this power can be carried out directly by the population. These problems are usually connected with the satisfaction of daily needs of people. This power, as well as public to be under construction on self-organizing and selfcontrol principles. Self-government institutions don't possess enforcement machinery. By the nature self-government institutions of citizens aren't completely nonstate structures, such as public, religious associations and other institutes of a civil society. Self-government is an obligatory element of structure of the state.

In this regard, it is necessary to take into account the self-government of citizens in our country, which is legally strengthened in a number of articles of the Constitution of the Republic of Uzbekistan, based on socioeconomic, spiritual, legal and political foundations. After all, this factor determines the democratic, legal nature of society, it recognizes that: man, his rights and freedoms are the highest value; the only source of state power is its multinational people; Establishment of rules on equality, freedom and obligations of citizens in all regions of the Republic of Uzbekistan; Social orientation of the policy of the Republic of Uzbekistan; unity of economic space; equal protection of all forms of property; political and ideological diversity; obligation to comply with the Constitution and laws of the Republic of Uzbekistan; The national legal system of the 
Republic of Uzbekistan includes compliance with internationally recognized principles and norms of international law and treaties.

\section{The critical approach}

Featuring local authorities on public associations: local governments are formed by the imperative injunction of the state, while the associations are formed by certain segments of the population on the voluntary principle, the scope of activities of public associations by the general rule is not part of public affairs, while the authorities local government may be vested with certain state powers, scope of activities of a public association can not be confined to the specific administrative and territorial unit, unlike local authorities, which always have clear territorial binding.

Today, citizens 'self-government is characterized as a state and public institution as a form of self-organization of the population. In the current situation, there is a dual nature of citizen self-government, and it, by its very nature, has the status of a collective state. For the effective functioning of the state should be a balance of state and local interests, common interests of the residents of each individual urban and rural settlement. The role of spokesman for local interests and is expected to play a self-governing citizen.

Self-government of citizens means, in a broad sense, the self-organization of society. It can function as an institution of power due to its two different natures, both collective and state. At present, citizens' self-government in Uzbekistan operates in the same manner and is guaranteed by the current Constitution. At the same time, citizen self-government operates in the form of territorial social self-government.
Finally, citizens also have the opportunity to conduct the first and second views of selfgovernment in a reciprocal manner. Any public authority has a public character, but not every public interest must necessarily have national significance. As for the dependence of selfgovernance from the state, it seems, its presence did not testify in favor of state or nonstate nature of self-government. And civil society and any individual depend on the state. Nature of the state is such that it may impose total control over any entities located within its jurisdiction, to put them in absolute dependence on his will.

At the same time, the generality of the principle of organization and functioning of the body of state power and the body of citizens' self-government cannot be ignored. These include: people's power; legitimacy; transparency; election of representative bodies, their separation and independence from each other and from social associations; limitation of rights and powers; taking public opinion into account; to carry out the tasks of centralization and decentralization in optimal balance.

Self-government of citizens is inherently peculiar features of the government. Therefore, some independence in matters of local importance is indispensable sign of selfgovernance can not exist without a single state economic, social, ideological, and other policies. Municipality of citizens can not be outside the system of state-power relations and to be totally independent from the state.

The question, therefore, is not that what the nature of those or other subjects of law is or is not it public, and in fact imposes a self-restraint by the state, to build a model of relationships with entities or not. Thus, the "publicity" - is 
just the common thing that unites the selfgovernment and state power. Each level of government has its own specific characteristics. Public authorities decide issues of state importance; self-government institutions address issues of local importance.

\section{Legal frame}

Regulation of self-government is one of the most important public policy priorities of the Republic of Uzbekistan. The modern state policy in the field of development of selfgovernment of citizens is based on the Constitution of the Republic of Uzbekistan (105 article) [5] and finds its expression in the law on self-government bodies of citizens, from 2013, and other legal acts.

The Constitution establishes that the only source of power is its multinational people, who exercise their power directly and through bodies of state authority and self-governance.

The main principles of the activities of citizens' self-government bodies are legality, priority of human rights, freedoms and legitimate interests, democracy, publicity, social justice, independence in solving local issues, public mutual assistance, social partnership, taking into account local customs and traditions [6].

In general, public policy in the field of development of self-government in Uzbekistan is based on following principles:

- The unity of purpose, direction, objectives and mechanisms for implementing public policies;

- Integrated approach to the implementation of public policy;

- Interaction and cooperation of public authorities in the field and self-governance bodies in implementing public policies (subsidiary);

- Continuity of government policies at different stages of reform;

- Comprehensive support for selfgovernance by the state;

- Non-interference of public authorities for the authorities of self-government;

- State control over the implementation of state bodies and officials of public policy.

As public authorities, closest to the population, citizens self-protect the interests of those citizens who are based at the joint of their residence in a particular area, to the inevitable interaction between the inhabitants of this territory. Therefore, self-governance is one of the fundamentals of democracy. At the same time self-government is recognized and guaranteed by the state as a form of selforganization of citizens to address local issues, provide the daily needs of each individual and the population as a whole.

Local government - one of the most important institutions, a necessary element of the democratic organization of political and social life of any country claiming to be legal.

\section{INNOVATION}

The practice of public administration has highlighted the importance of problems, which include issues of the institution of Mahalla. The main task is to substantiate the political expediency of measures, the implementation of which will make it possible to more effectively organize the structure and activities of public authorities and citizens' selfgovernment. Today, when we realize effective measures on achievement of the main strategic target defining the essence and the maintenance of our reforms - the construction 
of originally democratic state, free and safe life for our people, the great significance is taken by the further strengthening of a selfgovernment institute, increasing on a qualitatively new level of work spent in this direction.

One of the most important tasks of improving national statehood at the present stage is the reform of the institution of the Mahalla. The democratic structure determines the selforganization and self-development of each territorial entity, including the state as a whole. Self-government of citizens is an inseparable part of democracy, which is inextricably linked with the exercise of power. That is why in our country, which is confidently moving towards the formation of a strong rule of law, a just civil society, the role and significance of the Mahalla as a system of democratic governance is increasing. The regulation of the system of selfgovernment of citizens today is one of the main priorities of the state policy of Uzbekistan. The goals outlined in the Presidential Decree "On measures to improve the social and spiritual atmosphere in society, further support the institution of the Mahalla, as well as raising the system of working with families and women to a new level" [7] dated February 18, 2020, are gaining importance.

For the first time in Uzbekistan, the Ministry of Mahalla and Family Support was established, in accordance with the Presidential Decree, the Ministry is the authorized state body to develop and implement a unified state policy in the field of support of families, women and the elderly, protection of their rights and legitimate interests, cooperation with citizens' self-government bodies. For Uzbekistan, the formation of the Ministry for the Support of Mahalla and Family is a progressive step. The central tasks of the department were all-round assistance in the full-fledged formation of a social and spiritual environment in society, maintaining a unified state policy to strengthen the institution of the family, providing comprehensive support for women, developing proposals for improving the activities of citizens' self-government bodies, protecting their rights and legal interests, as well as improving the system Mahalla. It is this direction of the new ministry that corresponds to the ideas of a modern democratic state, where the highest value is a person, his rights and freedoms.

Taking into account the role of the Mahalla institute in the socio-spiritual life of our society, in order to support the staff of the sphere, March 22 was declared the "Day of the Mahalla system".

\section{CONCLUSION}

Analysis of theories of self-government should be from a position of connection to nature, government "public" and "state" began (the theory of dualism, self-governance). If selfgovernment is completely separated from the solution of state problems, it becomes a truly public, but the state will have to create a geographically "duplicate" of its system of government to address public issues at the local level that is economically inefficient. If self-government is completely subordinated to the state authorities, as a result we can receive not self-government of citizens, (as the form of democracy providing independent activity of the population under the decision of questions of local value), and local level of the government which will be, certainly, is effective in the decision of the problems put by the state, but thus will consider few interests of inhabitants of separate territories. 
Development of democratic principles of the organization and realization of selfgovernment of citizens in interests as the states, and on places should become the purpose of mutual relations of the government and self-government of citizens. So, creation of the effective mechanism of interaction of the state and self-government of citizens in the conditions of the proclaimed principle of independence still is one of key and most actual questions for today.

Each level of government has its own specific characteristics. Public authorities decide issues of state importance; self-government institutions address issues of local importance. The scope of the authorities of various government powers is distributed throughout the country, the power of self-government in each case a limited area. It is the state determines the general principles of selfgovernment and thus forms a model of relationship with self-government. Selfgovernment of citizens depends on the government; it receives exactly such degree of independence which will be defined for it by the government.

Thus, a system of self-governance of the public administration system is distinguished by certain characteristics. But, as can be seen, many of the features combined with a system of citizens' self-governance. To emphasize the differences between these forms of social control and at the same time to define their common purpose and coordinated, based on the principle of cohesion, functioning, some researchers rightly propose to use such a category as "public administration". Most important problem of the system of public administration can be defined as "the need to determine the optimum combination of state and local government as a special kind of social control that are different from other kinds of it".

The head of state has launched full-scale reforms aimed at developing democratic principles in the formation and operation of institutions of state power and selfgovernment of citizens. The transformation of democracy from a formal attribute of the state into a real political and legal institution and a mechanism that ensures the social legitimacy of power creates prospects for its development and further reform. But one thing can be said for sure: the course taken for the approval of a new institution of democracy in Uzbekistan is irreversible.

\section{REFERENCES}

1. Vahobov A. Local Government and Selfgovernment Bodies of State Power // The Republic of Uzbekistan is an independent state. - Tashkent.: Adolat, 1995.

2. Gayupova Sh.O. Democratic Processes in Traditional Uzbek Mahallas // Proceedings of the Republican scientific conference of young scientists dedicated to the 6oth anniversary of the Academy of Sciences of Uzbekistan. - Tashkent, 2003.

3. Abduvakhitov A. From a Strong State to a Strong Civil Society Mahalla: Historical Experience and Modern Time. Academy of Public Administration under the President of the Republic of Uzbekistan. Tashkent. Akademiya. 2014.

4. Shavkat Mirziyoyev: Mahalla should be the abode of peace and tranquility, mutual respect and education // URL: https://uza.uz/ru/posts/shavkat-mirziyeev- 
The American Journal of Political Science Law and Criminology (ISSN - 2693-0803)

Published: November 28, 2020 | Pages: 99-107

Doi: https://doi.org/10.37547/tajpslc/Volume02Issue11-16

makhallya-dolzhna-byt-obitelyu-mira-i-spok-

03-06-2017

5. The Constitution of the Republic of

Uzbekistan // URL:

https://lex.uz/docs/4032775

6. Law of the Republic of Uzbekistan "About the Self-Government institutions of Citizens // URL: https://www.lex.uz/acts/2156897

7. Decree of the President of the Republic of Uzbekistan "On measures to improve the social and spiritual atmosphere in society, further support of the mahalla institute, as well as raising the system of work with families and women to a new level" // URL: https://lex.uz/docs/4740345 